\title{
Repeatability of adaptability and stability parameters of common bean in unpredictable environments
}

\author{
Lidiane Kely de Lima(1), Magno Antonio Patto Ramalho(1), \\ Ricardo Augusto Diniz Cabral Ferreira(1) and Ângela de Fátima Barbosa Abreu ${ }^{(2)}$
}

\begin{abstract}
(1) Universidade Federal de Lavras, Departamento de Biologia, Caixa Postal 3.037, CEP 37200-000 Lavras, MG, Brazil. E-mail: lidianekely@yahoo.com.br, magnoapr@dbi.ufla.br, ricardo.cabral.agronomia@gmail.com (2)Embrapa Arroz e Feijão, Caixa Postal 179, CEP 75375-000 Santo Antônio de Goiás, GO, Brazil. E-mail: afbabreu@dbi.ufla.br
\end{abstract}

\begin{abstract}
The objective of this work was to estimate the repeatability of adaptability and stability parameters of common bean between years, within each biennium from 2003 to 2012, in Minas Gerais state, Brazil. Grain yield data from trials of value for cultivation and use common bean were analyzed. Grain yield, ecovalence, regression coefficient, and coefficient of determination were estimated considering location and sowing season per year, within each biennium. Subsequently, a analysis of variance these estimates was carried out, and repeatability was estimated in the biennia. Repeatability estimate for grain yield in most of the biennia was relatively high, but for ecovalence and regression coefficient it was null or of small magnitude, which indicates that confidence on identification of common bean lines for recommendation is greater when using means of yield, instead of stability parameters.
\end{abstract}

Index terms: Phaseolus vulgaris, biometry, genotype by environment interaction, plant breeding, quantitative genetic.

\section{Repetibilidade dos parâmetros de adaptabilidade e estabilidade do feijoeiro em ambientes imprevisíveis}

Resumo - O objetivo deste trabalho foi estimar a repetibilidade dos parâmetros de adaptabilidade e estabilidade do feijoeiro entre anos, dentro de cada biênio de 2003 a 2012, em Minas Gerais, Brasil. Os dados de produtividade de grãos provenientes de ensaios de valor de cultivo e uso de feijoeiro-comum foram analisados. A produtividade de grãos, a ecovalência, o coeficiente de regressão e o coeficiente de determinação foram estimados quanto a local e época de semeadura por ano, dentro de cada biênio. Posteriormente, realizou-se análise de variância destas estimativas, e a repetibilidade foi estimada nos biênios. A estimativa de repetibilidade quanto à produtividade de grãos, na maioria dos biênios, foi relativamente alta, mas, quanto à ecovalência, ao coeficiente de determinação e ao coeficiente de regressão, foi nula ou de pequena magnitude, o que indica maior confiança na identificação de linhagens de feijão a serem recomendadas, quando se usam as medidas de produtividade, em vez dos parâmetros de estabilidade.

Termos para indexação: Phaseolus vulgaris, biometria, interação genótipo por ambiente, melhoramento de plantas, genética quantitativa.

\section{Introduction}

Common bean is grown throughout Brazilian territory over the entire year and, therefore, under diverse environmental conditions. In this situation, the genotype by environment interaction is expected to be expressive, as shown in the literature (Pereira et al., 2010; Silva et al., 2011; Torga et al., 2013). For that reason, the Ministério da Agricultura, Pecuária e Abastecimento (Mapa) requires that the trials of value for cultivation and use (VCU) must be conducted in various environments, including diverse growing conditions, for the selection of cultivars with greater phenotypic stability (Brasil, 2006).

The term "environment" includes the growing conditions, and this involves locations, sowing seasons, years, and cropping practices, among others, or even a combination of these factors. As to variations of environments, Allard \& Bradshaw (1964) classified them as predictable and unpredictable. Predictable variations are those which occur in a systematic manner or are under human control. Unpredictable variations are those which fluctuate in an inconsistent manner, as for example, years, which may vary in 
regard to rainfall, temperature, relative humidity, and other factors.

Different methodologies are shown in the literature with a view towards the study of adaptability and stability (Cruz \& Carneiro, 2004; Oliveira et al., 2006; Pereira et al., 2009; Bernardo, 2010; Ramalho et al., 2012b). Nevertheless, it is not enough to simply estimate the stability parameter. It is necessary to verify if it is inheritable, because cultivars are evaluated with the hope that their performance will appear in the future, when their use by farmers will occur under environmental conditions certainly different from those under which they were evaluated (Gauch Júnior \& Zobel, 1988).

Information concerning the genetic control of stability parameters is not frequent. One method, sometimes used, makes it possible to estimate the repeatability of the adaptability and stability parameters, for which experiments should be conducted in each environment, with four replicates. Two analyses have to be performed, one with the data from the $1^{\text {st }}$ and $2^{\text {nd }}$ replicates, and the other with data from the $3^{\text {rd }}$ and $4^{\text {th }}$ ones. Thus, two groups of the parameter estimates are obtained in analyses involving the various environments. Analysis of variance in a randomized block design is then carried out, considering the results of each group of observation as replicates.

By this method, some estimates were obtained with common bean and other crops. For mean yield, repeatability $\left(\mathrm{r}_{\mathrm{yy}}^{2}\right)$ ranged from 0.40 to 0.98 ; for ecovalence $\left(\mathrm{W}_{\mathrm{i}}^{2 \%} \%\right.$ ), from -0.43 to 0.80 ; and for coefficient of determination $\left(\mathrm{R}^{2}\right)$, from 0.41 to 0.83 (Farias et al., 1998; Bruzi et al., 2007). The problem of this method, emphasized by the authors, is that the estimate of variation $\left(\mathrm{V}_{\mathrm{P}}\right)$ that composes the numerator of the expression of repeatability, not only contains the component of genetic deviation, but it also contains permanent environmental variations, which means that temperature and moisture of a single location are common to all the replicates. These estimates are therefore overestimated. In addition, they did not involve years, which is an unpredictable environmental factor. It would be important to obtain information on genetic control of stability parameters mainly involving the effect of years, which is an unpredictable environmental factor.

The objective of this work was to estimate the repeatability of the adaptability and stability parameters of common bean between years, within each biennium from 2003 to 2012, in Minas Gerais State, Brazil.

\section{Materials and Methods}

Yield data from trials of value for cultivation and use (VCU) carioca (beige grain with brown stripes) common-bean were used. The trials were conducted in Minas Gerais state by Embrapa Arroz e Feijão, Universidade Federal de Lavras, Universidade Federal de Viçosa, and by the Empresa de Pesquisa Agropecuária de Minas Gerais, from 2003 to 2012 (four biennia).

Environments were chosen within each biennium in which locations and sowing seasons repeated in the two years (Table 1). The number of common bean lines varied among biennia, with 20 in 2003/2004, 25 in 2005/2006, 26 in 2008/2009, and 25 in 2011/2012.

The experiments were set up following the minimum requirements established by Ministério da Agricultura, Pecuária e Abastecimento (MAPA) (Brasil, 2006) for VCU testing of common bean, as: randomized block design with three replicates, and plots of four four-meter length rows. Grain yield data were obtained considering the two center rows. No disease or pest control was performed.

Data from each environment, location and sowing season were subjected to analysis of variance, and the mean values were obtained. Then, joint analysis

Table 1. Environments used in each biennium for value for cultivation and use testing of common bean from 2003 to 2012, in Minas Gerais state, Brazil.

\begin{tabular}{cccc}
\hline 2003/2004 & 2005/2006 & 2008/2009 & $2011 / 2012$ \\
\hline Lavras/November ${ }^{(1)}$ & Lambari/February & Lambari/November & Lavras/November \\
Lavras/February & Lavras/February & Lavras/November & Lambari/November \\
Patos de Minas/ & Patos de Minas/ & Patos de Minas/ & Patos de Minas/ \\
February & February & November & November \\
Lambari/February & Viçosa/February & Coimbra/July & Lavras/July \\
Viçosa/February & Patos de Minas/July & Lambari/July & Patos de Minas/July \\
Coimbra/February & Sete Lagoas/July & Uberlândia/July & Lambari/July \\
- & Uberlândia/July & Florestal/February & Sete Lagoas/July \\
- & - & Lambari/February & Coimbra/July \\
- & - & Lavras/February & Lavras/February \\
- & - & Patos de Minas/ & Lambari/ \\
- & - & February & February \\
- & - & Sete Lagoas/ & Patos de Minas/ \\
- & - & February & February \\
- & & Uberlândia/ & Sete Lagoas/ \\
& & February & February \\
\hline
\end{tabular}

${ }^{(1)}$ Sowing month.

Pesq. agropec. bras., Brasília, v.48, n.9, p.1254-1259, set. 2013 DOI: 10.1590/S0100-204X2013000900009 
of variance per year was performed using $\mathrm{R}$ software (R Foundation for Statistical Computing, Vienna, AT), and Scott-Knott clustering test, at 5\% probability, according to Ramalho et al. (2012a).

The stability parameters for each year were estimated. Eberhart \& Russell (1966) stability analysis was carried by the following model: $\mathrm{y}_{\mathrm{ij}}=\mathrm{b}_{0 \mathrm{i}}+\mathrm{b}_{1 \mathrm{i}} \mathrm{I}_{\mathrm{j}}+\mathrm{V}_{\mathrm{d}_{\mathrm{ij}}}+\varepsilon_{\mathrm{ij}}$, in which: $y_{i j}$ is the estimated average for the $\mathrm{i}$ cultivar, in the $j$ environment; $b_{0 \mathrm{i}}$ is the intercept or mean of the $i$ cultivar; $b_{1 \mathrm{i}}$ is the regression coefficient of the $\mathrm{i}$ cultivar; and $\mathrm{Ij}$ is the environmental index. The environmental index $\left(\mathrm{I}_{\mathrm{j}}\right)$ uses the average of each environment $\left(\mathrm{y}_{\mathrm{j}}\right)$ as a measure of environmental fluctuation, and is determined by the following estimator: $I_{j}=\left(y_{j} / t\right)-(y . / t k)=y_{. j}-y$, in which: $y_{. j}$ is the total of the $j$ environment; $t$ is the number of environments; $k$ is the number of common bean lines; $y$ is the overall total; $\varepsilon_{\mathrm{ij}}$ is the experimental, medium error; and $\mathrm{V}_{\mathrm{d}_{\mathrm{ij}}}$ is the regression deviation of the $i$ cultivar in the $j$ environment.

The coefficient of determination $\left(\mathrm{R}_{\mathrm{i}}^{2}\right)$ was used instead of the regression deviations $\left(\mathrm{V}_{\mathrm{d}_{\mathrm{i}}}\right)$ because they provide essentially the same information and, as $\mathrm{R}^{2}$ ranges from 0 to $100 \%$, it is easier to make comparisons. The ecovalence in percentage $\mathrm{W}_{\mathrm{i}}^{2} \%$ was estimated (Cruz \& Carneiro, 2004). Ecovalence $\left(\mathrm{W}_{\mathrm{i}}^{2} \%\right)$ is a measure of type II agronomic stability, (Becker, 1981); it estimates the contribution of each line to the interaction. Since line $\mathrm{x}$ environment interaction is of a fixed nature, the significance of the ecovalence estimates $\left(\mathrm{H}_{0}: \mathrm{W}_{\mathrm{i}}^{2}=0\right)$ was tested by the mean square error, using the following expression:

$$
\mathrm{Fc}=\frac{\left(\mathrm{gW}_{\mathrm{i}}^{2} / \mathrm{g}-1\right) / \mathrm{a}^{-1}}{\mathrm{MS}_{\text {error }}} \sim \mathrm{F}_{\text {tab }}\left(\alpha \% ; \mathrm{a}-1 ; \mathrm{DF}_{\text {error }}\right)
$$

in which: $\mathrm{g}$ is number of common bean lines; and a is number of environments.

Pearson's correlation coefficient was estimated between mean grain yield, ecovalence, coefficient of determination $\left(R^{2}\right)$, and regression coefficient $\left(b_{i}\right)$.

With the estimates of mean grain yield, and $\mathrm{R}^{2}$ and $\mathrm{W}_{\mathrm{i}}^{2} \%$ obtained per year, analyses of variance were performed considering each year of the biennium as a replicate. Considering that the line has a fixed effect, repeatability $\left(\mathrm{r}_{\mathrm{yy}}^{2}\right)$ was estimated considering the year $\mathrm{y}$ and $\mathrm{y}^{\prime}$ in each biennium, by the expression $\mathrm{r}_{\mathrm{yy}}^{2}=\left(\mathrm{Q}_{1}-\mathrm{Q}_{2}\right) / \mathrm{Q}_{1}=\mathrm{COV}_{\mathrm{yy}} / \mathrm{V}_{\mathrm{F}}=\mathrm{V}_{\mathrm{P}} /\left[\mathrm{V}_{\mathrm{P}}+\left(\mathrm{V}_{\mathrm{E}} / 2\right)\right]$, in which: $\mathrm{Q}_{1}$ and $\mathrm{Q}_{2}$ are the mean square of common bean line and error, respectively, by the analysis of variance of each biennium; $\mathrm{COV}_{\mathrm{yy}}$ is the covariance between the performance of common bean lines in years y and y'; $\mathrm{V}_{\mathrm{F}}$ is the variance among line means; $\mathrm{V}_{\mathrm{P}}$ is the sum of square of genetic deviations between lines; and $\mathrm{V}_{\mathrm{E}}$ is the environmental variance.

\section{Results and Discussion}

Pearson's correlation between ecovalence and coefficient of determination were high and significant (Table 2). The closer is $\mathrm{R}^{2}$ to 100 , more stable is the lineage. Thus, $\mathrm{W}_{\mathrm{i}}^{2} \%$ and $\mathrm{R}^{2}$ should provide similar results. Estimates of correlation between $\mathrm{R}^{2}$ and $\mathrm{b}_{\mathrm{i}}$ were mostly high and significant, except for the years 2003 and 2011, which shows that the greater $b_{i}$ estimate, the better its adjustment to the regression line, and the higher was $\mathrm{R}^{2}$. For $\mathrm{W}_{\mathrm{i}}^{2} \%$ and $\mathrm{b}_{\mathrm{i}}$, all the estimates were low and nonsignificant, except for the years 2006 and

Table 2. Pearson's correlation coefficient between grain yield, ecovalence $\left(\mathrm{W}_{\mathrm{i}}^{2} \%\right)$, coefficient of determination $\left(\mathrm{R}^{2}\right)$, and regression coefficient $\left(b_{i}\right)$. Data obtained annually for the value for cultivation and use testing of common bean conducted in Minas Gerais state, Brazil, from 2003 to 2012.

\begin{tabular}{|c|c|c|c|c|}
\hline Year & Estimates & Yield & $b_{i}$ & $\mathrm{R}^{2}$ \\
\hline \multirow{3}{*}{2003} & $\mathrm{~W}_{\mathrm{i}}^{2} \%$ & $0.15^{\text {ns }}$ & $0.12 \mathrm{~ns}$ & $-0.88 * *$ \\
\hline & $\mathrm{R}^{2}$ & $0.01^{\mathrm{ns}}$ & $0.21 \mathrm{~ns}$ & - \\
\hline & $b_{i}$ & $0.51 *$ & - & - \\
\hline \multirow{3}{*}{2004} & $\mathrm{~W}_{\mathrm{i}}^{2} \%$ & $0.28^{\text {ns }}$ & $-0.40 \mathrm{~ns}$ & $-0.89 * *$ \\
\hline & $\mathrm{R}^{2}$ & $-0.23^{\mathrm{ns}}$ & $0.74 * *$ & - \\
\hline & $b_{i}$ & $-0.01^{\mathrm{ns}}$ & - & - \\
\hline \multirow{3}{*}{2005} & $\mathrm{~W}_{\mathrm{i}}^{2} \%$ & $-0.32^{\mathrm{ns}}$ & $-0.26 n s$ & $-0.91 * *$ \\
\hline & $\mathrm{R}^{2}$ & $0.50 * *$ & $0.54 * *$ & - \\
\hline & $\mathrm{b}_{\mathrm{i}}$ & $0.53 * *$ & - & - \\
\hline \multirow{3}{*}{2006} & $\mathrm{~W}_{\mathrm{i}}^{2} \%$ & $0.10^{\mathrm{ns}}$ & $0.41^{*}$ & $-0.58 * *$ \\
\hline & $\mathrm{R}^{2}$ & $0.19^{\mathrm{ns}}$ & $0.46^{*}$ & - \\
\hline & $b_{i}$ & $0.24^{\mathrm{ns}}$ & - & - \\
\hline \multirow{3}{*}{2008} & $\mathrm{~W}_{\mathrm{i}}^{2} \%$ & $-0.06^{\mathrm{ns}}$ & $-0.26 n s$ & $-0.79 * *$ \\
\hline & $\mathrm{R}^{2}$ & $0.17^{\mathrm{ns}}$ & $0.78 * *$ & - \\
\hline & $\mathrm{b}_{\mathrm{i}}$ & $0.22^{\mathrm{ns}}$ & - & - \\
\hline \multirow{3}{*}{2009} & $\mathrm{~W}_{\mathrm{i}}^{2} \%$ & $0.03^{\mathrm{ns}}$ & $-0.39 *$ & $-0.93 * *$ \\
\hline & $\mathrm{R}^{2}$ & $-0.02^{\mathrm{ns}}$ & $0.69 * *$ & - \\
\hline & $b_{i}$ & $0.06^{\mathrm{ns}}$ & - & - \\
\hline \multirow{3}{*}{2011} & $\mathrm{~W}_{\mathrm{i}}^{2} \%$ & $-0.33^{\text {ns }}$ & $0.36^{\mathrm{ns}}$ & $-0.73 * *$ \\
\hline & $\mathrm{R}^{2}$ & $0.05^{\mathrm{ns}}$ & $0.31^{\mathrm{ns}}$ & - \\
\hline & $b_{i}$ & $-0.27^{\mathrm{ns}}$ & - & - \\
\hline \multirow{3}{*}{2012} & $\mathrm{~W}_{\mathrm{i}}^{2} \%$ & $-0.37^{\mathrm{ns}}$ & $0.13^{\mathrm{ns}}$ & $-0.74 * *$ \\
\hline & $\mathrm{R}^{2}$ & $0.22^{\mathrm{ns}}$ & $0.53 * *$ & - \\
\hline & $\mathrm{b}_{\mathrm{i}}$ & $-0.06^{\mathrm{ns}}$ & - & - \\
\hline
\end{tabular}

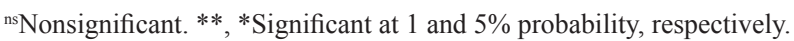


2009. Estimates of correlations between $\mathrm{W}_{\mathrm{i}}^{2} \%, \mathrm{R}^{2}$ or $b_{i}$ and grain yield were of small magnitude, and most of them were nonsignificant. Thus, in principle, it is possible to identify productive and stable common bean lines. Results similar to these were obtained under other conditions (Gonçalves et al., 2007; Silva Filho et al., 2008; Cargnelluti Filho et al., 2009; Rocha et al., 2010).

The existence of significant difference among the evaluated lines was shown by the fact that they grouped in more than one class by Scott-Knott test (Table 3). However, in each year, the four highest yielding lines always belonged to the same group by the aforementioned test. It is interesting to observe that coincidence in the lines classified as having better or worse performance, in the two years, varied according to the biennium. Coincidence was small in the two last biennia (2008/2009 and 2011/2012).

The four lines with $\mathrm{W}_{\mathrm{i}}^{2} \%$ lowest estimate, in all cases, were nonsignificant, which means they did not differ from zero, and, therefore, contributed little to the interaction (Tabela 3). In contrast, the four common bean lines with the highest contribution to interaction showed $\mathrm{W}_{\mathrm{i}}^{2} \%$ estimate different from zero. It was possible to identify common bean lines differing in agronomic stability, since ecovalence $\left(\mathrm{W}_{\mathrm{i}}^{2} \%\right)$ is a measure of the type II agronomic stability, as already mentioned (Becker, 1981).

For mean grain yield, the effect of years did not vary between the biennia, except for the 2011/2012 biennium (Table 4). In principle, the VCU is carried out in two years, presuming that the behavior of each biennium represents the climatic conditions which the future cultivar - recommended to farmers - will confront (Gauch Júnior \& Zobel, 1988).

Common bean line source of variation was significant for grain yield in all the biennia, except for the 2011/2012 (Table 4), showing that the mean performance of the lines was different in each biennium, which is desirable because breeders will be able to identify lines which may be recommended to farmers by means of this variable. Performance repeatability of common bean lines in the two years of each biennium was relatively high, except for the last biennium. This fact is particularly expressive, considering that year is an unpredictable environmental factor (Allard \& Bradshaw, 1964).
As the ecovalence estimate was obtained in percentage within each year, the sum of squares of the year source of variation in the analysis of variance was null (Table 4). Similarly to $b_{i}$, as for each year the average of $b_{i}$ was one, there was no variation between years. There was no significant difference among common bean lines for ecovalence. As a result, the repeatability estimate of stability parameters was practically null.

Table 3. Best and worst common bean lines selected by means of grain yield and estimates of ecovalence $\left(\mathrm{W}_{\mathrm{i}}^{2} \%\right)$, per year, within each biennium.

\begin{tabular}{|c|c|c|c|c|}
\hline \multirow[t]{2}{*}{ Biennium } & \multicolumn{2}{|c|}{ Yield $^{(1)}$} & \multicolumn{2}{|c|}{$\mathrm{W}_{\mathrm{i}}^{2} \%$} \\
\hline & Year 1 & Year 2 & Year 1 & Year 2 \\
\hline \multirow{9}{*}{$2003 / 2004$} & $11 \mathrm{~A}$ & $13 \mathrm{~A}$ & 1 & 16 \\
\hline & $12 \mathrm{~A}$ & $11 \mathrm{~A}$ & 7 & 3 \\
\hline & $10 \mathrm{~A}$ & $12 \mathrm{~A}$ & 11 & 2 \\
\hline & $9 \mathrm{~A}$ & $10 \mathrm{~A}$ & 16 & 19 \\
\hline & $\ldots$ & ... & $\ldots$ & ... \\
\hline & $5 \mathrm{C}$ & $15 \mathrm{C}$ & $2 * *$ & $9 * *$ \\
\hline & $17 \mathrm{C}$ & $17 \mathrm{C}$ & $12 * *$ & $1 * *$ \\
\hline & $14 \mathrm{C}$ & $16 \mathrm{C}$ & $18 * *$ & $13^{* *}$ \\
\hline & $20 \mathrm{C}$ & $14 \mathrm{C}$ & $15^{* *}$ & $5 * *$ \\
\hline \multirow{9}{*}{$2005 / 2006$} & $19 \mathrm{~A}$ & $16 \mathrm{~A}$ & 3 & 23 \\
\hline & $17 \mathrm{~A}$ & $18 \mathrm{~A}$ & 4 & 24 \\
\hline & $3 \mathrm{~A}$ & $19 \mathrm{~A}$ & 19 & 22 \\
\hline & $16 \mathrm{~A}$ & $2 \mathrm{~A}$ & 25 & 19 \\
\hline & ... & $\ldots$ & $\ldots$ & $\ldots$ \\
\hline & $10 \mathrm{~B}$ & $12 \mathrm{~B}$ & $1 * *$ & $4 * *$ \\
\hline & $11 \mathrm{~B}$ & $11 \mathrm{~B}$ & $10 * *$ & $2 * *$ \\
\hline & $21 \mathrm{C}$ & $9 \mathrm{~B}$ & $12 * *$ & $20 * *$ \\
\hline & $12 \mathrm{C}$ & $21 \mathrm{~B}$ & $17 * *$ & $6 * *$ \\
\hline \multirow{9}{*}{$2008 / 2009$} & $9 \mathrm{~A}$ & $25 \mathrm{~A}$ & 23 & 23 \\
\hline & $15 \mathrm{~A}$ & $20 \mathrm{~A}$ & 1 & 1 \\
\hline & $18 \mathrm{~A}$ & $9 \mathrm{~A}$ & 17 & 24 \\
\hline & $16 \mathrm{~A}$ & $12 \mathrm{~A}$ & 2 & 11 \\
\hline & $\ldots$ & $\ldots$ & $\ldots$ & $\ldots$ \\
\hline & $1 \mathrm{C}$ & $13 \mathrm{C}$ & $21 * *$ & $15^{* *}$ \\
\hline & $4 \mathrm{D}$ & $2 \mathrm{C}$ & $7 * *$ & $19^{* *}$ \\
\hline & $5 \mathrm{D}$ & $5 \mathrm{C}$ & $3 * *$ & $7 * *$ \\
\hline & $2 \mathrm{D}$ & $6 \mathrm{C}$ & $6^{* *}$ & $8 * *$ \\
\hline \multirow{9}{*}{$2011 / 2012$} & $18 \mathrm{~A}$ & $25 \mathrm{~A}$ & 24 & 11 \\
\hline & $13 \mathrm{~A}$ & $2 \mathrm{~A}$ & 5 & 13 \\
\hline & $7 \mathrm{~A}$ & $18 \mathrm{~A}$ & 13 & 2 \\
\hline & $9 \mathrm{~A}$ & $1 \mathrm{~A}$ & 8 & 25 \\
\hline & $\ldots$ & $\ldots$ & $\ldots$ & $\ldots$ \\
\hline & $11 \mathrm{~B}$ & $14 \mathrm{C}$ & $14 * *$ & $8 * *$ \\
\hline & $23 \mathrm{~B}$ & $21 \mathrm{C}$ & $11^{* *}$ & $10 * *$ \\
\hline & 14B & $15 \mathrm{C}$ & $22 * *$ & $21^{* *}$ \\
\hline & 10B & $8 \mathrm{D}$ & $23 * *$ & $15^{* *}$ \\
\hline
\end{tabular}

${ }^{(1)}$ Means followed by equal letters, in the columns, belong to the same group by the Scott-Knott test, at $5 \%$ probability. $* *, *$ Significant at 1 and $5 \%$ probability, respectively. Hypothesis test for ecovalence $\left(\mathrm{H}_{0}: \mathrm{W}^{2}{ }_{\mathrm{i}}=0\right)$. 
Information on genetic control of the estimates of stability parameters is scarce in the literature, mainly due to the difficulty of obtaining it. Pacheco et al. (1999) and Cruz \& Carneiro (2004) proposed the use of diallel crosses evaluated in various environments to estimate the general and specific combination capacity of stability parameters. This strategy is very difficult to apply, due to the difficulty of performing all the crosses of the diallel and, moreover, evaluating them in a large number of environments.

The strategy used in this work can apply to any VCU experiment, since there is a coincidence of locations and sowing dates in both years. It should be emphasized that any study method of interaction can be applied. Repeatability estimates in the literature, as already mentioned, are overestimated because the numerator of the expression of $\mathrm{r}_{\mathrm{yy}}^{2}$ contains not only genetic deviation, but also permanent environmental variations. The present study confirms the results found in literature for the estimates $\mathrm{r}_{\mathrm{yy}}, \mathrm{W}_{\mathrm{i}}^{2} \%$, and $\mathrm{R}^{2}$ (Farias et al., 1998; Bruzi et al., 2007).

Grain yield proved to be a character more favorable for selection than the parameters of adaptability and stability, based on $\mathrm{r}_{\mathrm{yy}}^{2}$ estimates, as already mentioned. However, for the parameters ecovalence $\left(\mathrm{W}^{2} \mathrm{i} \%\right)$, coefficient of determination $\left(\mathrm{R}^{2}\right)$, and regression coefficient $\left(b_{i}\right)$, breeders will rarely succeed in the selection, due to low repeatability from one year to another.

Table 4. P-value of the analysis of variance and estimates of repeatability $\left(\mathrm{W}_{\mathrm{i}}^{2} \%\right)$, means of grain yield $\left(\mathrm{kg} \mathrm{ha} \mathrm{h}^{-1}\right)$, estimates of ecovalence, and regression coefficient (bi) by biennium. Data obtained for the value for cultivation and use (VCU) trials in Minas Gerais state, Brasil, for common bean, from 2003 to 2012 .

\begin{tabular}{|c|c|c|c|c|c|}
\hline \multirow[t]{2}{*}{ Estimate } & \multirow{2}{*}{$\begin{array}{c}\text { SV } \\
\text { Years }\end{array}$} & \multicolumn{4}{|c|}{ Biennia } \\
\hline & & $2003 / 2004$ & $2005 / 2006$ & $2008 / 2009$ & $2011 / 2012$ \\
\hline \multirow{3}{*}{ Means of Yield } & \multirow{2}{*}{ Lines } & 0.51 & 0.11 & 0.47 & 0.00 \\
\hline & & 0.02 & 0.00 & 0.00 & 0.26 \\
\hline & $\mathrm{r}_{\mathrm{yy}^{\prime}}^{2}$ & 0.62 & 0.72 & 0.66 & 0.23 \\
\hline \multirow[t]{2}{*}{$\mathrm{W}_{\mathrm{i}}^{2} \%$} & Lines & 0.59 & 0.46 & 0.26 & 0.53 \\
\hline & $\mathrm{r}_{\mathrm{yy}^{\prime}}^{2}$ & 0.00 & 0.04 & 0.23 & 0.00 \\
\hline \multirow{3}{*}{$\mathrm{R}^{2}$} & Years & 0.03 & 0.00 & 0.01 & 0.00 \\
\hline & Lines & 0.58 & 0.26 & 0.65 & 0.64 \\
\hline & $\mathrm{r}_{\mathrm{yy}^{\prime}}^{2}$ & 0.00 & 0.23 & 0.00 & 0.00 \\
\hline \multirow{2}{*}{$\mathrm{b}_{\mathrm{i}}$} & Lines & 0.18 & 0.46 & 0.27 & 0.53 \\
\hline & $\mathrm{r}_{\mathrm{yy}^{\prime}}^{2}$ & 0.36 & 0.02 & 0.23 & 0.03 \\
\hline
\end{tabular}

\section{Conclusions}

1. The estimate of repeatability for grain yield in most of the biennia is relatively high, whereas for ecovalence, coefficient of determination, and regression coefficient, it is null or of small magnitude.

2. Due to higher repeatability estimates, confidence in identification of common bean lines to be recommended is greater when based on yield instead of stability parameters.

\section{Acknowledgments}

To the professors of the Universidade Federal de Viçosa (UFV), and to researchers of Empresa de Pesquisa Agropecuária de Minas Gerais (Epamig) and Embrapa Arroz e Feijão (Cnpaf), who kindly granted the data for undertaking this study; and to Conselho Nacional de Desenvolvimento Científico e Tecnológico (CNPq), for scholarships.

\section{References}

ALLARD, R.W.; BRADSHAW, A.D. Implications of genotype-environmental interactions in applied plant breeding. Crop Science, v.4, p.503-508, 1964. DOI: 10.2135/cropsci1964.0 011183X000400050021x.

BECKER, H.C. Correlations among some statistical measures of phenotypic stability. Euphytica, v.30, p.835-840, 1981. DOI: 10.1007/BF00038812.

BERNARDO, R. Breeding for quantitative traits in plants. $2^{\text {nd }}$ ed. Woodbury: Stemma, 2010. 390p.

BRASIL. Ministério da Agricultura, Pecuária e Abastecimento. Requisitos mínimos para determinação do valor de cultivo e uso de feijão (Phaseolus vulgaris), para a inscrição no registro nacional de cultivares - RNC. Brasília: MAPA, 2006. Anexo I.

BRUZI, A.T.; RAMALHO, M.A.P.; ABREU, A. de F.B.; FERREIRA, D.F.; SENA, M.R. Homeostasis of common bean populations with different genetic structures. Crop Breeding and Applied Biotechnology, v.7, p.111-116, 2007.

CARGNELUTTI FILHO, A.; STORCK, L.; RIBOLDI, J.; GUADAGNIN, J.P. Associação entre métodos de adaptabilidade e estabilidade em milho. Ciência Rural, v.39, p.340-347, 2009. DOI: $10.1590 / \mathrm{S} 0103-84782008005000080$.

CRUZ, C.D.; CARNEIRO, P.C.S. Modelos biométricos aplicados ao melhoramento genético. Viçosa: Ed. da UFV, 2004. 480p.

EBERHART, S.A.; RUSSEL, W.A. Stability parameters for comparing varieties. Crop Science, v.6, p.36-40, 1966. DOI: 10.2135/cropsci1966.0011183X000600010011x.

FARIAS, F.J.C.; RAMALHO, M.A.P.; CARVALHO, L.P. de; MOREIRA, J. de A.N.; COSTA, J.N. da. Repetibilidade dos 
parâmetros de estabilidade na cultura do algodoeiro herbáceo. Pesquisa Agropecuária Brasileira, v.33, p.457-461, 1998.

GAUCH JÚNIOR, H.G.; ZOBEL, R.W. Predictive and postdictive success of statistical analyses of yield trials. Theoretical and Applied Genetics, v.76, p.1-10, 1988. DOI: 10.1007/BF00288824.

GONÇALVES, E.C.P.; DI MAURO, A.O.; CARGNELUTTI FILHO, A. Adaptabilidade e estabilidade de genótipos de soja conduzidos em duas épocas de semeadura, na região de Jaboticabal - SP. Científica, v.35, p.61-70, 2007.

OLIVEIRA, G.V.; CARNEIRO, P.C.S.; CARNEIRO, J.E. de S.; CRUZ, C.D. Adaptabilidade e estabilidade de linhagens de feijão comum em Minas Gerais. Pesquisa Agropecuária Brasileira, v.41, p.257-265, 2006. DOI: 10.1590/S0100-204X2006000200010.

PACHECO, C.A.P.; CRUZ, C.D.; SANTOS, M.X. dos. Association between Griffing's diallel and the adaptability and stability of Eberhart and Russel. Genetics and Molecular Biology, v.22, p.451-456, 1999. DOI: 10.1590/S1415-47571999000300027.

PEREIRA, H.S.; MELO, L.C.; FARIA, L.C. de; DEL PELOSO, M.J.; CABRERA DIAZ, J.L.; WENDLAND, A. Indicação de cultivares de feijoeiro-comum baseada na avaliação conjunta de diferentes épocas de semeadura. Pesquisa Agropecuária Brasileira, v.45, p.571-578, 2010. DOI: 10.1590/S0100204X2010000600006.

PEREIRA, P.S.; MELO, L.C.; FARIA, L.C. de; DEL PELOSO, M.J.; COSTA, J.G.C. da; RAVA, C.A.; WENDLAND, A. Adaptabilidade e estabilidade de genótipos de feijoeiro-comum com grãos tipo carioca na Região Central do Brasil. Pesquisa
Agropecuária Brasileira, v.44, p.29-37, 2009. DOI: 10.1590/ S0100-204X2009000100005.

RAMALHO, M.A.P.; ABREU A. de F.B.; SANTOS J.B. dos; NUNES, J.A.R. Aplicações da genética quantitativa no melhoramento de plantas autógamas. Lavras: Ufla, 2012b. 522p.

RAMALHO, M.A.P.; FERREIRA, D.F.; OLIVEIRA, A.C. de. Experimentação em genética e melhoramento de plantas. Lavras: Ufla, 2012a. 305p.

ROCHA, V.P.C.; MODA-CIRINO, V.; DESTRO, D.; FONSECA JÚNIOR, N. da S.; PRETE, C.E.C. Adaptabilidade e estabilidade da característica produtividade de grãos dos grupos comerciais carioca e preto de feijão. Semina: Ciências Agrárias, v.31, p.39-54, 2010.

SILVA FILHO, J.L. da; MORELLO, C. de L.; FARIAS, F.J.C.; LAMAS, F.M.; PEDROSA, M.B.; RIBEIRO, J.L. Comparação de métodos para avaliar adaptabilidade e estabilidade produtiva em algodoeiro. Pesquisa agropecuária Brasileira, v.43, p.349-355, 2008. DOI: 10.1590/S0100-204X2008000300009.

SILVA, C.A.; ABREU, A. de F.B.; RAMALHO, M.A.P.; CARNEIRO, J.E. de S. Implicações da origem das linhagens na magnitude da interação com ambientes. Pesquisa Agropecuária Brasileira, v.46, p.720-728, 2011. DOI: 10.1590/ S0100-204X2011000700007.

TORGA, P.P.; MELO, P.G.S.; PEREIRA, H.S.; FARIA, L.C.; DEL PELOSO, M.J.; MELO, L.C. Interaction of common beans cultivars of the black group with years, locations and sowing seasons. Euphytica, v.189, p.239-248, 2013. DOI: 10.1007/ s10681-012-0793-y.

Recebido em 18 de junho de 2013 e aprovado em 7 de agosto de 2013

Pesq. agropec. bras., Brasília, v.48, n.9, p.1254-1259, set. 2013 DOI: 10.1590/S0100-204X2013000900009 